IP Periodica Polytechnica Architecture

47(1), pp. 30-40, 2016

DOI: 10.3311/PPar.8913

Creative Commons Attribution (i)

RESEARCH ARTICLE

\section{Outline of the Design and Functioning of Green Shading Systems, Compared to Industrial Products}

\author{
Rita Pataky ${ }^{1 *}$
}

Received 15 February 2016; accepted after revision 19 July 2016

\begin{abstract}
On the building of the BME-Odooproject, which participated in the Solar Decathlon competition in 2012, we were able to perform on-site impact measurements with deciduous (Parthenocissus quinquefolia, Parthenocissus tricuspidata) and evergreen (Hedera helix) plant-shading systems. The analysis of the bio-shaders' mechanism of action and data obtained during the research, proved that bio-shaders comply with the most important criteria of shading systems (to allow through the least energy ratio, reflect the largest share possible, minimise absorption and transmit the absorbed amount outward). This is due to the plant's structure, physiological processes, evaporation, and air movement. The bio-shadings meet and in certain cases, approach or even exceed these requirements; their efficiency is comparable to industrial blinds. As well as being a new form of architectural element, they also have many other ecological benefits; bio-shaders can play an important role in the building's energy balance, particularly in reducing the summer heat load.
\end{abstract}

\section{Keywords}

green façade, green wall, climbing plants, VGS (Vertical Greenery System), bio-shading, green shading, g-value, Solar Heat Gain Coefficient, $F_{c}$-value, general shading factor

\footnotetext{
${ }^{1}$ Department of Building Constructions, Faculty of Architecture

H-1111, Budapest, Müegyetem rkp. 3, Hungary

*Corresponding author, e-mail: rpataky@epsz.bme.hu
}

\section{Introduction}

While in the early 1900 s, the average ratio of the glazed surface on a façade was approximately $15 \%$, in the mid-1980s it had risen above 80\% (Széll, 2001; Gábor-Zöld, 1981). Today, there are buildings where this ratio reaches $100 \%$, which is accompanied by an increase in the summer heat load and winter heat loss. The winter heat loss can be reduced by an improved U-value in the glazed structures (Becker, 2014), and by mitigating the emitted heat flows at night. With regard to the comfort conditions of interior spaces during the winter, the passive solar energy gain of glazed structures is favourable, but significantly increases the heat load of buildings during the summer (Gábor-Zöld, 1981), leading to increased energy consumption for cooling. Effective shading is essential to reduce this adverse process and ensure a good interior climate. The shading can be placed on the exterior or interior, between glass layers, or instead of shading blinds, the glass itself can have solar-protective properties. The efficiency varies depending on the type of shade used, although the external, movable or adjustable types are the most efficient. (Becker, 2015; Gábor, 1979; Csoknyai and Szalay, 2012; Széll, 2001)

It is conspicuous in contemporary architecture that plants related to buildings and their surroundings are ignored. However, vegetal motifs appear on many concrete, metal or glass coatings as decoration (eg.: :mlzd: School Expansion Wettingen/ Ch (Enkerli, 2009); Bellemo\&Cat: Multi-dwelling buildings Northcota/Australian (Kreykenbohn, 2009); teamk2 (architects) ZT: Apartmanhouse Innsbruck/A (Schaefer, 2011); WWAA Architects: Polish exhibition pavilion, Sanghai (Gutai, 2010); Kis Péter Architect Atelier: Laposa Winery (Bojár, 2010); René Vain Zuuk Architekten: Project X Almere/Nl (Kolleeny, 2010), kadawittfeldarchitektur: Kindergarten (Anon., 2010a), EM2N, Mathias Müller - Daniel Niggli: Project for District Centre, Zurich-Aussersihl (Anon., 2002)). Often, the large glass surfaces themselves act as a mirror and multiply the surrounding nature, or the building just fits into its environment due to reflection (e.g.: Johannes Breschneider: Toilettebox Lauteshofes/D (Anon., 2013b); Architekten EM2N: retrofitting of City Garden Hotel Zurich/Ch (Enkerli, 2010), kadawittfeldarchitektur: NEW 
Baluhaus, Mönchengladbach-Rheydt (Mehl, 2015)). In many cases, a perforated or mesh-shaped coating covers the entire building (e.g.: Li Xiaodong Atalier: Library Liyuan/China (Anon., 2013a); AAVP: Kindergarten and school in SaintDenis /F (Anon., 2013c); :mlzd: School Expansion Wettingen/ Ch (Enkerli, 2009); Estudio Lamela: Call Centers, Quérataro/ Mexiko (Anon., 2010b); WWAA Architects: Polish exhibition pavilion, Shanghai (Gutai, 2010); Miralles Tagliabue EMBBT: Spanish exhibition building Shanghai (Gutai, 2010); Andreas Bründler: Swiss exhibition pavilion Shanghai (Gutai, 2010); Elmar Ludescher: School Lauterach/A (Ludescher, 2004); Herzog \& de Meuron: Messe Basel/Ch (Pawlitschko, 2013); Grüntuch Ernst Architekten: Marthashof Berlin/D (Käpplinger, 2013)). The commonness of glazed surfaces located behind the cover is substantial; these covers also serve as shadings.

Based on this, a question arises: why not use actual plants instead of plant motifs on the façade? These are also able to provide a homogenous, light-transmissive shield cladding (Pataky, 2013).

One possible realization of green façades is bio-shading (Pataky, 2011; 2012), which can provide a new architectural appearance and influence, among the existing systems and individual solutions.

Proposals for using these structures have already been raised in the early period of green architecture (Pataky, 2012) and appear regularly in books and publications dealing with ecological and environmentally conscious architecture (eg.: Daniels, 1995; Kursche et al., 1982) and publications analysing the effects of green façades (eg.: Fll, 2014; Hoyano, 1988; Ip et al., 2010; Jafaar et al., 2013; Manso et al., 2015; Ottelé et al., 2011; Papadakis et al., 2001; Pérez et al., 2011a, b.; Sheweka et al., 2011; 2012; Wong et al., 2010).In the history of gardens, the tradition of bio-shading can be traced back to antiquity, and in the late $19^{\text {th }}$ century and early $20^{\text {th }}$ century, even in Hungary, they were popular architectural elements (Pataky, 2015b).Nevertheless, bio-shadings are still less widespread compared to other application of green façades; it is also a less researched area.

In this paper, only the bio-shadings located in front of glass structures and their influence will be discussed.

\section{Bio-shading systems}

Most of us think of climbing plants rooted in soil as bio-shading, but it is worth reviewing various ways of establishing green façades before discussing the several types of bio-shading.

\subsection{Green façade establishment possibilities (Pataky, 2010; 2011; 2015a)}

\section{A. Climbing plants (with or without support system)}

Vegetated façades can be established by direct greening with self-clinging climbers or indirectly with a supporting system installed in front of the wall; annuals, deciduous or evergreen perennial plants can be used.
In certain situations, espaliers are established in front of the façades, typically with orchard plants; these create a flat surface with an auxiliary support system, shaping a defined pattern or grown freely.

\section{B. Planter system}

In this case, in front of the wall surfaces, herbaceous or woody plants are typically placed horizontally, planted from above into linear or spot-fixed planting pots.

C. Vertical root zone systems (e.g. carrier system or living walls)

These are green claddings forming a closed green surface where herbaceous or woody plants are planted into a rooting zone (planting method from the front) in modular panels filled with growing media, or in felt systems.

\subsection{Options for establishing bio-shadings}

Bio-shadings can be established with almost all versions of green façades (Pataky, 2010; 2011; 2013; 2015a), in many cases, with structures similar to conventional shading systems.

\section{A. Bio-shading systems with climbing plants}

Species that do not require support systems (e.g. direct greening)

Self-clinging climbing plants that do not require a support system (such as Hedera helix, Parthenocissus quinquefolia, Parthenocissus tricuspidata) can cling to glass surfaces, but examples of this method have emerged mostly spontaneously; this application is not recommended.

Species in need of support systems (e.g. indirect greening)

The most frequent application, regarding the various forms of construction and species, is when plants are grown on support systems placed in front of glazed structures, mass walls or glass walls. The plants may be rooted in the soil at the bottom of the building, or in the planting medium of a green roof on an intermediate level of the building. Due to the growing properties of the plants, the maximum height is limited in the case of plants rooted in the soil at the bottom of the building or planting medium of a green roof, and more time is necessary to achieve the expected density. Surfaces well above the maximum height of the plants can be covered if the plants are rooted in planting pots or containers fixed on the wall or on a support structure in front of the wall (e.g.: SERA Architects and Cutler Andreson Architects: Federal Building, Portland (Weinstein, 2010), Augustin and Frank: Institut of Physics, Berlin - Adlershof (Zuber, 2013), Enrique Browne and Borja Huidobro: Consorcio - Santiago Building (1993) (van Uffelen, 2011), Mario Cucinella Architects: Ex Ducati/I (2008) (van Uffelen, 2011), Fink+Jocher: Student Residence, University Campus of TU München, Graching/D (2005) (Köhler, 2012), Perkins+Will: The Centre for Interactive Research 
on Sustainability, The University of British Columbia, Vancouver/Ca (Keegan, 2012), Kissler+Effgen Architekten BDA: Lecture Hall and Institute Building of PTH St. Georgen, Frankfurt am Main/D (2004) (FLL, 2014), Molestina Architekten + Swanke Hayden Connell Architects: Tekfen Levent Ofis, Istanbul/Tü (2011) (FLL, 2014), Diener \& Diener Architekten: Stücki Shopping, Basel/Ch (2009) (FLL, 2014)). This group includes the bio-shadings installed with espaliers. However, in Hungary there is no historical background of these, mostly it is the Vitis-type that is common.

There is a special case of supporting structures requiring bio-shadings run with climbing plants: similar to folding shutters, moveable boards, or tilting slats around a vertical axis, the boards or slats are themselves the supporting structure for the plants rooted in a planting pot located at the bottom of the structure.

\section{B. Planter system}

If the planting container lines or planting plots fit together tightly, shading in front of the wall surface cannot be established with containers above each other.

Only if the height difference of the container lines is at least higher than the container itself can they function as shading. Herbaceous plants are mostly used in this system. (e.g.: Kengo Kuma \& Associates: Z58, Shanghai, China (2006) (van Uffelen, 2011)). However, this solution also has a significant impact on darkening the internal space. As shading, a minimum of 50-100 cm distance between the lines is optimum, typically with hanging plants (e.g.: Antal Fekete (Finta Studio), Gábor Turányi and Bence (T2a), landscape architect: György Sloszjár: Budapest, XI. Bercsényi utca Újbuda Városközpont Allee és Simplon Udvar (Varga, 2009)) Edward Cullinan Architects Studio: Li Ka Shing Library, Singapore Management University 2006. (Lee, 2006?)).

\section{Vertical root zone systems (eg. carrier system)}

The vertical root zone systems typically form a closed surface, and function more as a darkener; therefore they cannot be set as shading. Shading can only be considered in similar cases as sliding boards or tilting slats with a vertical axis. In this case, the board or slat provides the carrier structure bearing the vertical root zone.

The bio-shading systems similar to 'traditional' boards or slats, with climbing plants or vertical root zone systems, are currently more a theoretical possibility. During their development, it has been technically difficult to provide a supply of moisture and nutrients together with the drainage of excess leachate in such a way as to ensure the shield is moveable manually or automatically. It is also an important aspect that these mechanical systems should not adversely affect the aesthetic appearance of the façade. Another difficulty is to harmonize the growing properties of the plant, the size of the structural shading panel, and the cultivation (e.g.: to allow the necessary pruning around the moving parts) in the case of climbing plants.

Consequently, these specific systems will not be the subject of the rest of this paper. This paper covers bio-shading systems made of climbing plants.

\section{Impact assessment of bio-shading systems}

We had the opportunity to run on-site measurements to assess the impact of different bio-shading systems on the "Odoo" building (Pataky et al., 2014). This was within the project of "Further analysis of the effective utilization of the BME Odoo project Solar Decathlon", under its supporting framework "New Széchenyi Plan ED_13-1-2013-0005 program". After a long and difficult preparation phase, the measurements commenced in March 2015.

Three identical glass sliding doors were appointed as a glazed test surface. (Fig. 1) In front of two doors, bio-shadings (climbing plants run on a supporting structure) were placed, while the third acted as a reference. Two different types of plants were trained on the shields: pre-grown evergreen on the first one (Hedera helix) - A3, and deciduous plants, grown from new shoots, on the other one (Parthenocissus quinquefolia, Parthenocissus tricuspidata)-A2. Due to extreme heat in the summer and the lack of an automatic water supply, the growth rate of the deciduous plants was significantly reduced (the Parthenocissus tricuspidata grew higher faster but did not spread horizontally). Additionally, the deciduous plants covered the measuring instruments relatively late, only in September. Accordingly, data to compare both glazed surface-associated shading systems and the reference surface were only derived from the autumn months. Because the shading system data from Parthenocissus will not be available until next year, the article contains only the analysis of the shading system using Hedera helix.

During the on-site measurements (Fig. 1-2), the following data were recorded in one-minute intervals:

- global solar radiation to the vertical plane (measured with pyranometers - 'P' - located above the sliding doors);

- external air temperature and humidity (measured with temperature and humidity sensor - 'T/Rh' - located above the doors, safely from radiation);

- air temperature and humidity in the bio-shading system (temperature and humidity sensor - ' $\mathrm{T} / \mathrm{Rh}$ ' - located in the bio-shading system);

- mid-pane glass temperature: interior and exterior surface temperature (measured with external and internal thermocouples- ' $\mathrm{T}$ ' - placed on the glass surfaces), mid-pane glass heat flux density (measured with a heat flux density meter stamp - 'q' - on the inner surface of the pane);

- indoor air temperature and humidity (measured with temperature and humidity sensors - ' $\mathrm{T} / \mathrm{Rh}$ ' - in the interior, located behind the pane); 


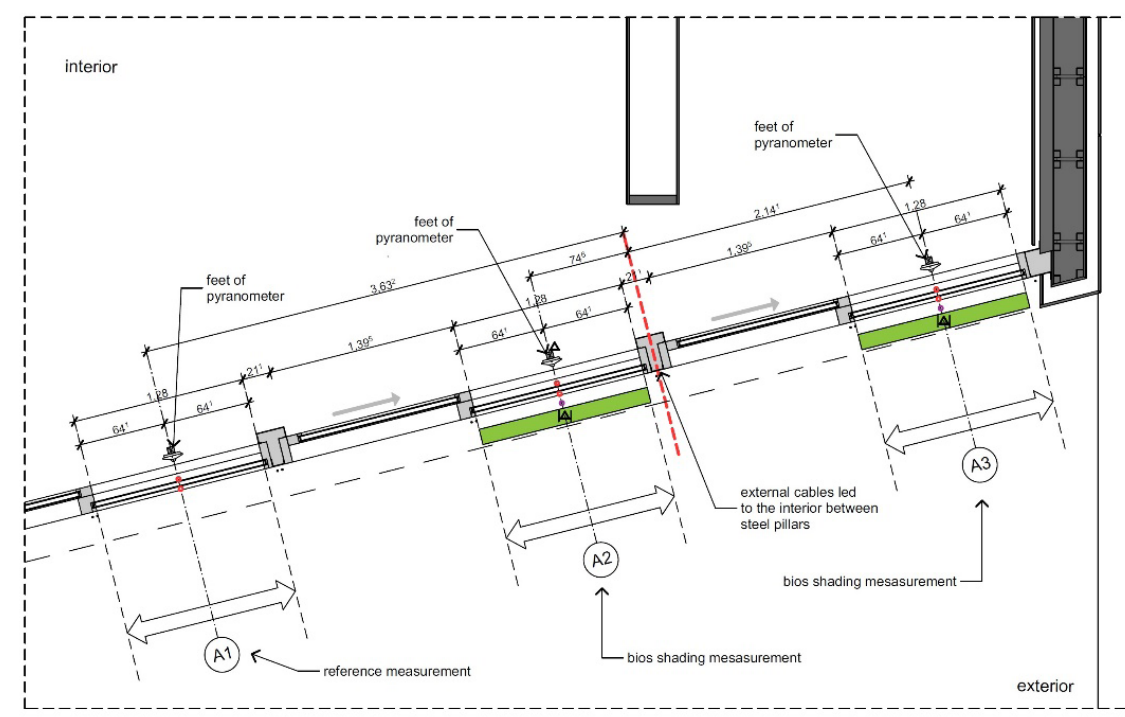

Fig. 1 Bio-shadings and sensors placed in front of the glass surfaces of Odoo (Bakonyi-Pataky)

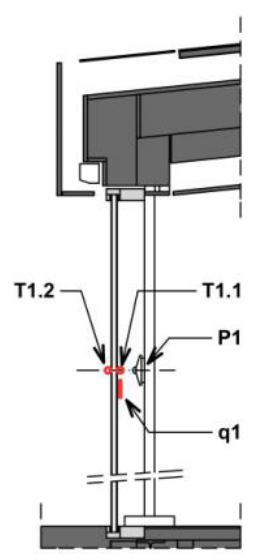

(A1)
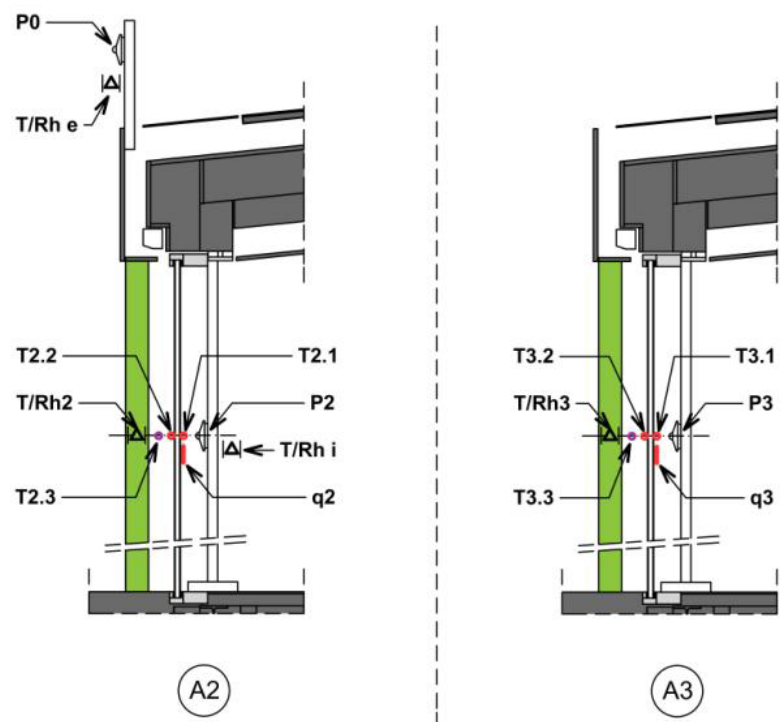

Fig. 2 Location of sensors in each section of the different cases: A1 reference pane, A2 bio-shading with deciduous plants,

A3 bio-shading with evergreen plants (Bakonyi-Pataky)

- solar radiation in the interior, transmitted by the glass structure or the glazed surface associated shading system (direct transmission, measured with pyranometer - ' $\mathrm{P}$ '-).

The panes built into the sliding door are three-layer insulating glass sheets with a total thickness of $58.75 \mathrm{~mm}$, covered with two Low-E coatings, $\tau_{\mathrm{e}}=0.35, \mathrm{~g}=0.46$. The layer structure of the glass panes from the outside inwards: $1^{\text {st }}$ pane: $8.00 \mathrm{~mm}$ Float Glass Extra Clear (Guardian) (EN 410) with ClimaGuard Premium T (Guardian) in $2^{\text {nd }}$ position $-16 \mathrm{~mm}$ : air 10\%, argon $90 \%$ - $2^{\text {nd }}$ pane: $6.00 \mathrm{~mm}$ Float Glass ExtraClear (Guardian) tempered glass - $18 \mathrm{~mm} \mathrm{10 \%}$ air, argon $90 \%-3^{\text {rd }}$ pane: $10.76 \mathrm{~mm}$ LamiGlass ExtraClear 5(0.76)5 (Guardian) with ClimaGuard Premium (Guardian) in $5^{\text {th }}$ position.

The data obtained from the measurements during the impact assessment is compared to data in the literature and other published research results.

\section{Impact mechanism of bio-shadings}

The following are important characteristics of shading structures associated with glazed structures (Becker, 2015; Gábor, 1979).

The associated structure should:

- transmit the least proportion of the energy from solar radiation;

- reflect the largest proportion of the energy from solar radiation;

- absorb as little as possible from the total energy of solar radiation;

Because the absorbed energy radiation may cause additional thermal load towards the interior, the absorbed energy proportion should be transmitted outwards.

In the case of bio-shadings, the shading effect is provided primarily by the leaves; then by the supporting structure -the 
planting pots and their "scaffolding", with some provided by the branches, shoots and flowers.

\subsection{Energy}

\subsubsection{Energy distribution of plants}

In case of leaves, depending on their size, surface, smoothness and local conditions, $5-30 \%$ of the global radiation is transmitted, $5-30 \%$ is reflected, $10-50 \%$ is emitted by thermal radiation and heat transfer, $5-20 \%$ is utilized by photosynthesis, and $20-40 \%$ is used for evapotranspiration of soil moisture or their humidity (Kursche et al., 1982; Köhler, 2012). (Fig. 3) The 25-60\% of energy consumption for photosynthesis and evapotranspiration does not apply to any other type of shading. Plants emit at least $25 \%$ less energy than any other traditional associated structure. In other words, the vegetation acts as if at least $25 \%$ less radiation energy is reaching the surface. (It does not apply in the case of shields, where the reflection can be $60-90 \%$.)

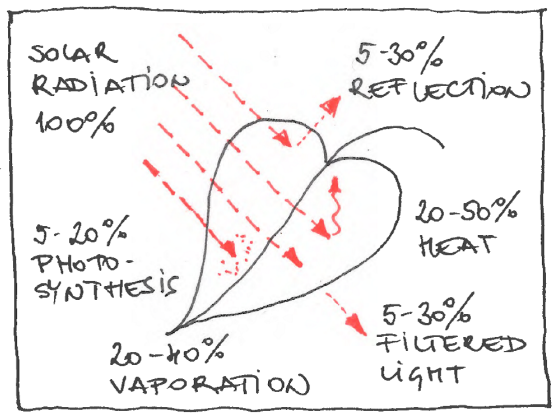

Fig. 3 Solar energy utilization of a leaf (source: as a result of Kursche et al., 1982)

\subsubsection{Ventilation}

Summer heat-load mitigation is an important feature of the air gap between a wall and a cladding in case of ventilated double skin façades (Gábor-Zöld, 1981): the ventilated air in the gap substracts heat from the surrounding surfaces. In the case of closed shadings (venetian blinds, canvas, and roller shutters, mostly with hidden box and guide rail) this air movement cannot develop; therefore heat-substraction cannot occur. Photosynthesis is a process used by plants driven by solar radiation: their leaves rise, operating as automatic solar sensors, turning towards the light as if tilting slats. Between the rising leaves and the glazed structure, the "chimney effect" results in air movement - even if the glass surface is close to the shade and heat-substraction occurs.

\subsubsection{Direct solar radiation transmission}

The leaves form a multi-layered structure that creates a closed surface while still allowing light to be transmitted.

While the external pyranometer measured $600 \mathrm{~W} / \mathrm{m}^{2}$ global radiation on $8^{\text {th }}$ of July 2015 , behind the reference glass, the direct transmission rate was $200 \mathrm{~W} / \mathrm{m}^{2}$; behind the glass pane associated with common ivy shading, it was $120 \mathrm{~W} / \mathrm{m}^{2}$ (Fig. 4).
These values on a warm day (12 $2^{\text {th }}$ of August 2015.) were as follows: $650 \mathrm{~W} / \mathrm{m}^{2} 220 \mathrm{~W} / \mathrm{m}^{2}$ and $90 \mathrm{~W} / \mathrm{m}^{2}$. Despite the higher global radiation, the direct radiation behind the glass shaded by common ivy was less because of the increased growth of the leaves, and the increased coverage. The data clearly shows that compared to the good quality reference glass $\left(\mathrm{U}=0.6 \mathrm{~W} / \mathrm{m}^{2} \mathrm{~K}\right)$, the glass pane associated with bio-shading transmits nearly half of the direct solar radiation.

On winter nights, in a closed position, the moveable shields can reduce the radiative heat loss from glazed structures; this reduction potential applies only for evergreen bio-shadings, but in this case, solar gain is limited during the daytime. Solar gain during daytime is unhindered in the case of deciduous bioshadings in winter; however, the radiative nighttime heat loss is not reduced.

For both types of bio-shadings, another favourable feature is that the branches may decrease heat substraction during windy weather due to convection heat transfer.

\subsubsection{Absorbed energy, heat load of the surroundings}

The shading structures absorb a portion of solar energy depending on their material, colour and surface treatment (e.g.: light-reflective coatings); consequently, they can become significantly hot around midday $\left(40-60{ }^{\circ} \mathrm{C}\right)$, with the absorbed heat transmitted towards their surroundings by thermal radiation and heat transfer.

Based on experiments performed so far, according to literature data, the absorbed energy proportion is relatively high in the case of plants; however, their temperature does not rise above air temperature even in the hottest hours. This was also confirmed by our measurements: when the air temperature was significantly higher than $40^{\circ} \mathrm{C}$, the measured air temperature between the plants did not exceed $42^{\circ} \mathrm{C}$, and while the reference glass surface temperature was $53^{\circ} \mathrm{C}$, during the daytime, the glass behind the bio-shading did not exceed $42^{\circ} \mathrm{C}$ (Fig. 5-6).

At the same time, on the inside of the reference glass pane, the heat flux density was $160 \mathrm{~W} / \mathrm{m}^{2}$, while the inside of the glass shaded by common ivy was measured at $42 \mathrm{~W} / \mathrm{m}^{2}$ (Fig.7)

These data show that the indoor heat load from absorption is significantly lower in case of bio-shadings; the results are identical to the work of other researchers: Papadakis et al. (1999); Ip et al. (2003); Wong et al. (2009); Perez et al. (2008-2009); Jaafar et al. (2013); Susurova et al. (2013).

\subsubsection{Vaporization}

In the hottest summer daytime periods, similar to other research, Perez et al. (2008-2009); Jaafar et al. (2013), the relative humidity in bio-shadings repeatedly exceeded the humidity of the air. The lower temperature is the result of the increased evaporation, which substracts heat from its environment, resulting in lower air temperatures. 


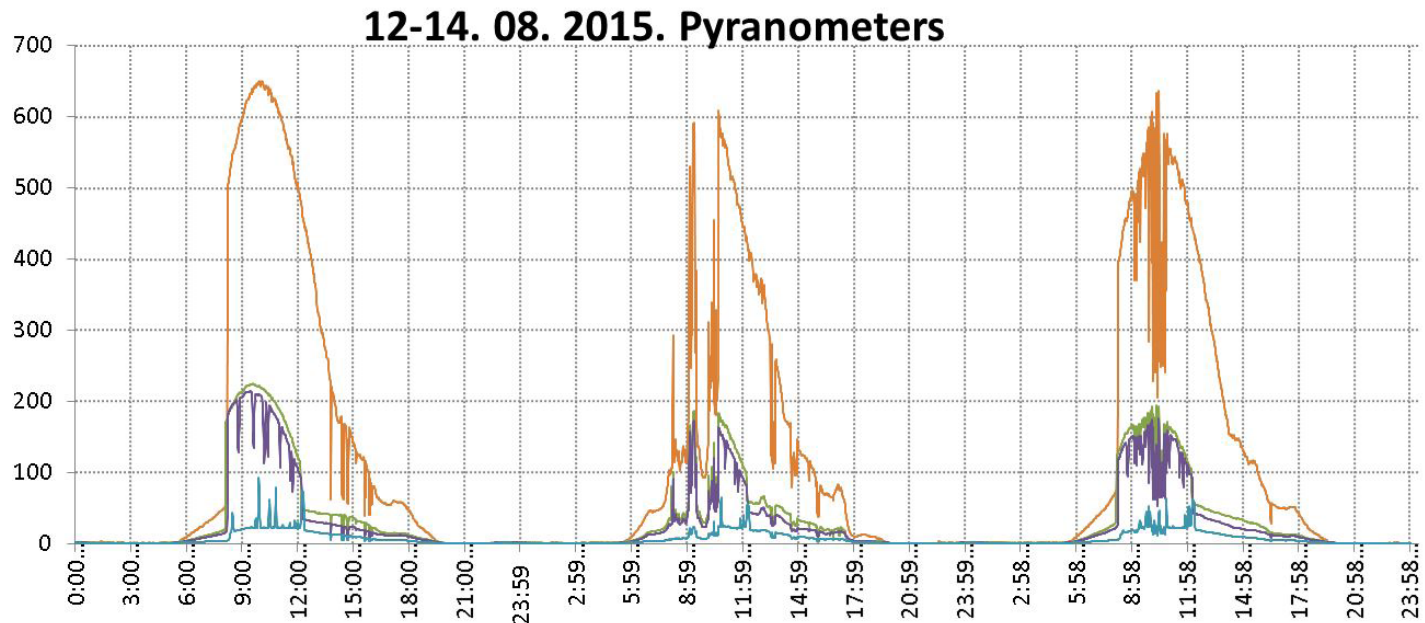

outdoor pyranometer

A1: pyranometer

A2: pyranometer

A3: pyranometer

Fig. 4 Values of global solar radiation and direct solar transmission measured from 12-14 August 2015.

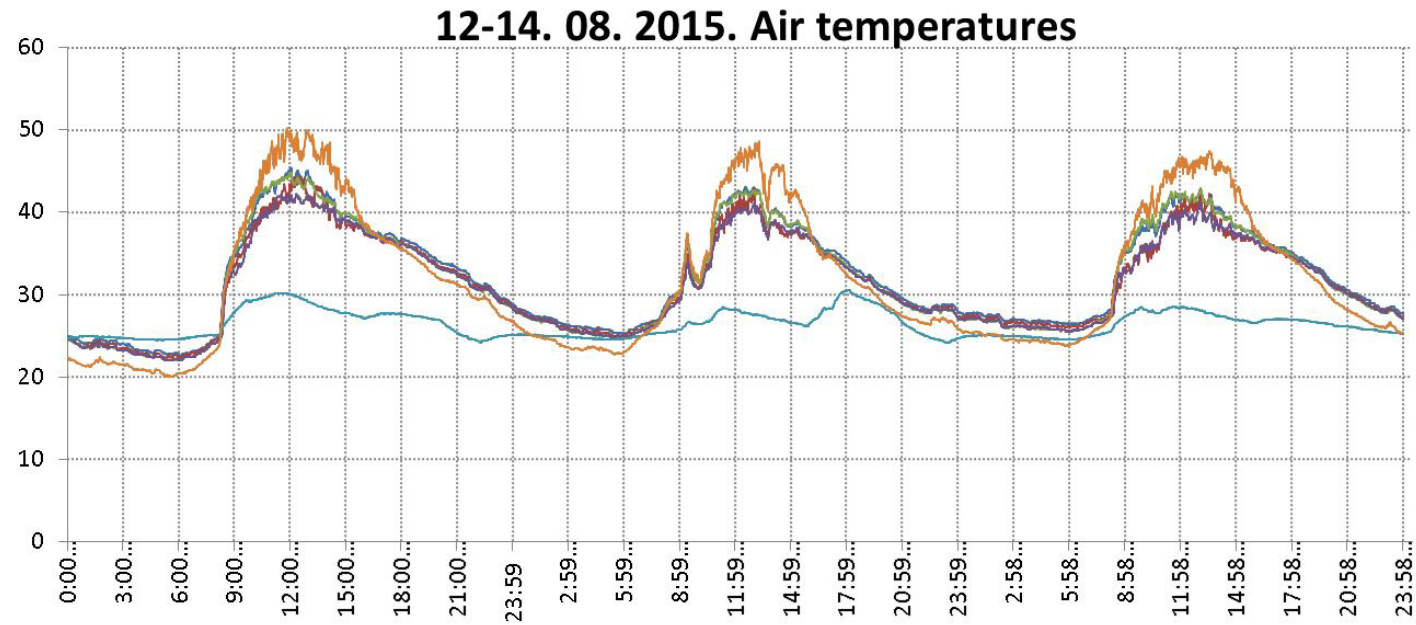

$\begin{array}{ll}\text { - A2 air temperature in the vegetation } & \text { A2 air temperature in the air gap } \\ \text { A3 air temperature in the air gap } & \text { - } 33 \text { air temperature in the vegetation }\end{array}$

Fig. 5 Air temperature values 12-14 August 2015. (Bakonyi-Orbán-Pataky)

12-14. 08. 2015. Surface Temperatures

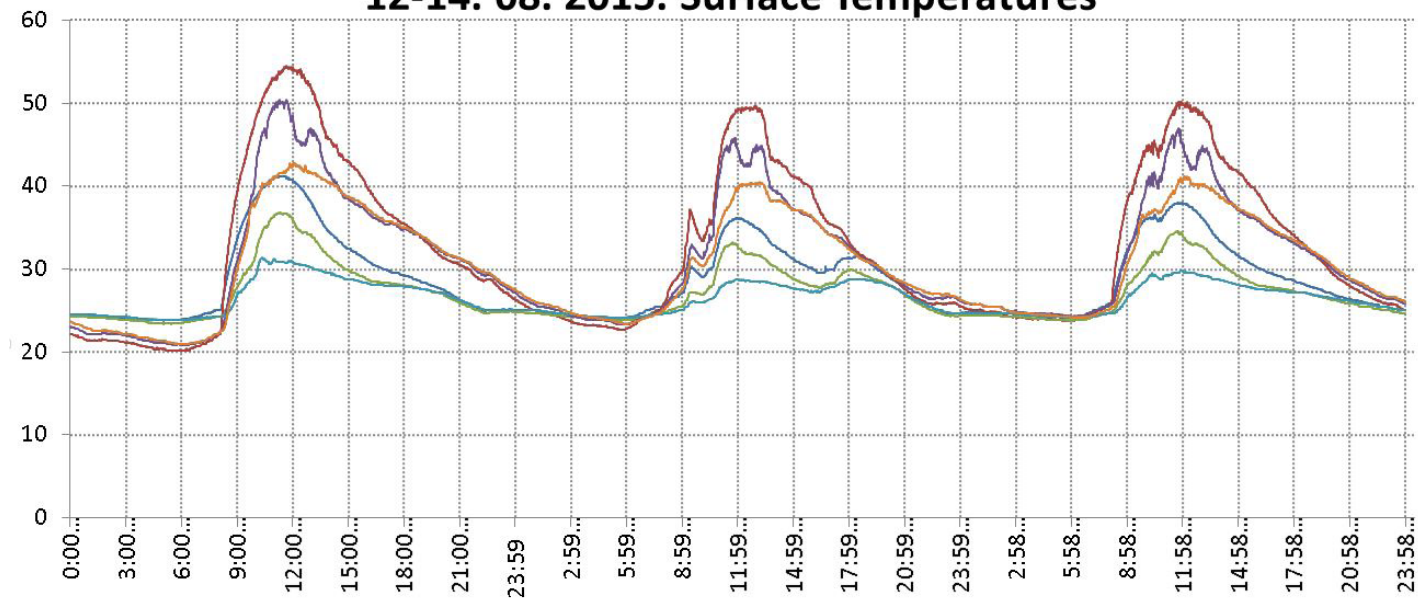

$\begin{array}{lll}-\mathrm{A} 1 \text { internal surface temperature } & \text { A1 external surface temperature } & -\mathrm{A} 2 \text { internal surface temperature } \\ -\mathrm{A} 2 \text { external surface temperature } & -\mathrm{A} 3 \text { internal surface temperature } & -\mathrm{A} 3 \text { external surface temperature }\end{array}$

Fig. 6 Surface temperature values 12-14 August 2015. (Bakonyi-Orbán-Pataky) 
12-14. 08. 2015. Heat Fluxes

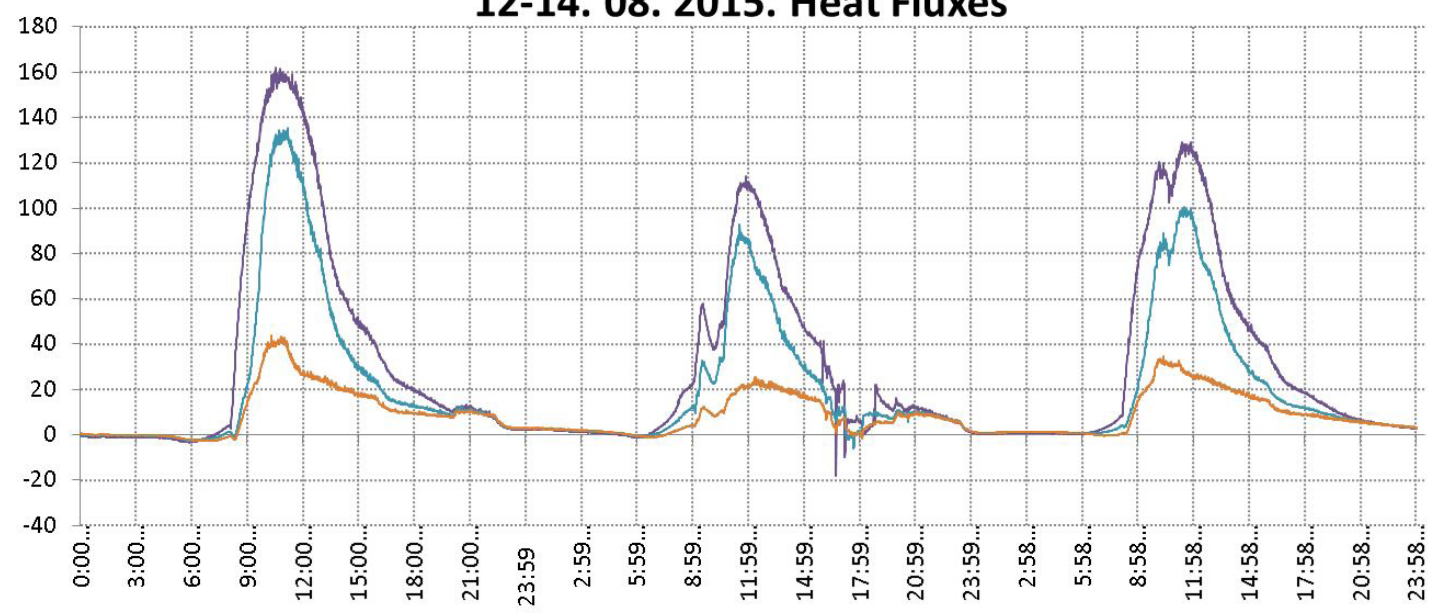

- A1 heat flux sensor

A2 heat flux sensor

_ A3 heat flux sensor

Fig. 7 Heat flux density values 12-14 August 2015. (Bakonyi-Orbán-Pataky)

Published data demonstrates an impact on air humidity by vegetation within a height of 10-12 times that of the plants (Ormos, 1967), but the horizontal effect of bio-shading is less; an approximately $20 \mathrm{~cm}$ thick layer of vegetation has an impact on the environment of at least $2 \mathrm{~m}$ into the surroundings.

\subsection{Daylighting, visual contact}

Solar transmission should be evaluated not only regarding thermal aspects but also in terms of lighting (Keegan, 2012). In Hungary, protection is needed against overheating during 1200 hours of summer (if the position of the Sun is steeper than $40^{\circ}$ in the period between 17 April to 28 August), and against overcooling in 720-1200 hours of winter from the annual total of 8760 hours. In the 6360-6840 hours transitional period, the target is solar energy utilization (Gábor, 1979; Széll, 2001). Concerning lighting, there are an estimated 5000 daylight hours of the 8760 total hours in a year, but only 3600 hours are considered to reach the $5000 \mathrm{~lx}$ reference value. Based on this, in the remaining hours, additional light is necessary along with natural lighting, or replacement artificial light is needed instead of daylight.

The fixed or closed shields can further worsen this situation. A window, covered completely by a blind (e.g.: lowered rolls, lowered closed venetian blinds, closed shutters) eliminates visual contact between the exterior and the interior, and restricts the view; similarly, natural light must be replaced by artificial lighting. These effects reduce the feeling of comfort, with closed shadings causing more unfavourable conditions regarding microclimate and energy consumption than the use of less energy-efficient shading.

The goal is to maintain visual contact and to transmit the greatest proportion of light in the visible light spectrum (380$780 \mathrm{~nm}$, light transmission factor " $\tau$ ”) using, for example, translucent polyester fabrics, or in the case of venetian blinds, perforated slats, and different positions.
The single leaves of a bio-shading form a closed system, but as a multi-layer structure, perfect coverage in all three dimensions is typically not formed (perforated surface). The light transmission is highly influenced by the distance between the vegetation and the glazed structure, the leaf density and the number of planes; this can also be affected by maintenance (pruning). Suitable light transmission can be achieved even in the case of very vigorously growing plants, although visual contact may be limited.

Unfortunately, this issue is still very under-researched; consequently, such a clear statement cannot be drawn as to which types of shadings provide the minimum lighting requirements for indoor workplaces; similarly, which types of species and standards for a chosen system (MSZ EN, 2012).

In Hungary, deciduous or annual plants are suggested for bio-shading systems or species with a growing period that overlaps the protection period (April-August); this is to avoid excessive energy consumption due to low light transmission.

\subsection{Security}

Movable shadings must meet wind-resistance standards (ITRS, 2012; MSZ EN, 2004); however, above a certain wind speed, they cannot remain in a lowered position. Thus, in windy but sunny weather, the mobile shadings may not participate in reducing the interior heat load. This situation will not occur in the case of bio-shadings; however, the recently more frequent wind loads must be considered (Hrabovszky-Horvath, 2015) during the design of the support system, and plant container fixing.

\subsection{Summary}

According to this, in addition to various experiments (Ip et al., 2010; Jafaar et al., 2013; Papadakis et al., 2001; Pérez et al., 2011b) and computer simulations (Susorova et al., 2013; Wong, 2009), our research also showed that bio-shaders 
comply with the most important criteria of shading systems through the plant's structure, physiological processes, evaporation, and air movement. The bio-shadings meet, and in certain cases approach or even exceed these requirements.

\section{Technical parameters, comparability of shadings}

To characterise shadings, the shading coefficient "SC" has been in use (Durchlassfaktor, coefficient d'ombrage, "b" - b factor), which is still used in parallel with other measuring values. The shading coefficient compares total energy transmission to the energy transmitted through a $3 \mathrm{~mm}$ thick single layer of normal float reference-glass.

$$
q=N \times I_{s r g}
$$

where the energy flow passes through the reference structure: $I_{\text {srg }}$, or through the examined structure: $\mathrm{q}\left(\mathrm{W} / \mathrm{m}^{2}\right)$.

The shading coefficient is a scalar value, between 0 and 1 . In the case of the reference structure, the total energy transmission is $\sim 85-87 \%$; that is $g_{\text {reference }} \approx 0.85-0.87$. The shading coefficient is specified by the following formula (Gábor, 1979; Gábor-Zöld, 1981)

$$
N=g / g_{\text {reference }}
$$

For external shadings, it is typically $\mathrm{N} \leq 0.2$ (Gábor, 1979). However, the reference to the German VDI 2078 guidelines (VDI, 2015) is a 2-layered insulating float glass where $g_{\text {reference }}=$ 0.8 , instead of the $3 \mathrm{~mm}$ thick glass. Between the two coefficients, there is a difference of approximately 13\%, which must be considered during the detailed calculations (MSZ EN, 2012). For proper calculations, the reference method must be known for the specific shading.

Currently, the shading structures associated with glass structures are described by a "g"-value, the "SHGC" Solar Heat Gain Coefficient (Solar Factor - SF, Energiedurchlass-grad, facteur de transmission totale de l'énergie solaire ou facteur solaire) (MSZ EN, 2005; 2011; Reith, 2012). It expresses the proportion of penetrated solar radiation energy in the 300-2500 nm wavelength spectrum specified in standard MSZ EN 410. This value includes all forms of heat gain: the direct radiation energy yield transmitted by the structure $\left(Q_{\text {direct }}\right)$, and the energy flows entering the room by absorbed energy $\left(Q_{\text {secondary }}\right)$, by heat transfer and its radiation. The g-value is measured under the perpendicular angle of incidence and depends on the material and colour of the shield, as well as the type of installation. The $\mathrm{g}$-value is a scalar value between $0-1$.

$$
g=\left(Q_{\text {direct }}+Q_{\text {secondary }}\right) / Q_{\text {TOT }}
$$

where $\left(Q_{\text {direct }}+Q_{\text {secondary }}\right)$ is the transmitted solar radiation through the glass structure associated with the shading structure, and $Q_{\text {Tот }}$ is global solar radiation.

The shading structures themselves can be characterised by the general shading factor " $F_{c}$ " (formerly “z"), which expresses the shading-impact itself. This value can be between $0-1, F_{c}=1$ if there is no shield at all.

$$
F_{c}=g_{\text {ТОТ }} / g \text { or } g_{\text {ТОТ }}=g \times F_{c}
$$

where

$\mathrm{g}_{\text {Тот }}$ is a measured value, the total energy transmission in case of a glass pane with closed external shading

$\mathrm{g}$ is a value specified according to EN 13363-1, e.g.: $\mathrm{UGL}=1.20 \mathrm{~W} / \mathrm{m}^{2} \mathrm{~K}, \mathrm{~g}=0.59$, whereas for a double-layer insulating float glass reference structure, $\mathrm{g}=0.8$.

It is clear that the general shading factor depends on the referred glazed structure. Therefore, it is important to be aware of the referred type of glass. In most cases, the $\mathrm{F}_{\mathrm{c}}$-value is specified by the $\mathrm{g}=0.8$ reference structure, thereby $\mathrm{F}_{\mathrm{c}}=0.05-0.5$ in the case of external shading.

It is clear that the determination of the actual performance of industrial blinds or the comparison of different shades is a challenge. In advanced energy calculations, these data, in their current form, cannot be used because the different (e.g. glazed, solar-protective) types of glass have different spectral properties, and the different types of glass associated even with the same shield have a different g-value (Solar Heat Gain Coefficient).

For determining bio-shading properties, other researchers have conducted series of measurements (e.g.: Ip et al., 2010; Jafaar et al., 2013; Papadakis et al., 2001; Pérez et al., 2011b), and also defined measures for technical performance. Unfortunately, the publications are not always detailed enough to be able to compare or apply the performance measures because the conditions of measurement and the used structures are often unknown, or the measurement methods are not equal to the measurements of the industrial shading products, or simply, the final data is not comparable. Thus, different data can be found, for example:

- in case of bio-shadings consisting of climbing plants on support systems (eg. indirect greening)the $\mathrm{F}_{\mathrm{c}}$-value $=0.3$ to 0.62 (according to DIN 4108-2, referring to the publication of Baumann - Baumann,R., 1980: Pflanzliche Verschattungselemente an der Gebäudeoberfläche als Maßnahme zur Reduzierung der Strahlungsbelastung unter sommerlichen Bedingungen, Kassel - (FLL, 2014));

- in the case of shading plants Parthenocissus quinquefolia and Wisteria sinensis, the shading effect is $70-95 \%$ (in Senatverwaltung for Stadtentwicklung Berlin (Hrsg.) (2010): Konzepte der Regenwasserbewirtschaftung, Gebäudebegrünung, Gebäudekühlung, Leitfaden für Planung, Bau, Betrieb und Wartung, www.gebaudekuehlung. de/Sen-Stadt_Regenwasser_dt_gross.pdf (FLL, 2014));

- the direct solar radiation transmission of Virginia Creeper (Parthenocissus quinquefolia) is between 0.43 to 0.13 (Ip et al., 2010).

The summary and evaluation of data from the research of the Odoo building's bio-shading is ongoing. Final data, considering 
Table 1 General shading factors $\left(F_{c}\right)$ of different external shading structures based on various sources. Although it is not stated in technical literature, values are commonly based on the EN 13363-1+A1 standard and refer to the thermal transmittance value of double clear glass $\left(\mathrm{U}=3.0 \mathrm{~W} / \mathrm{m}^{2} \mathrm{~K}\right)(\mathrm{Pataky}, 2015)$

\begin{tabular}{llll}
\hline External shading structure & $\begin{array}{l}\mathrm{F}_{\mathrm{c}} \text {-value based on DIN } \\
4108-2: 2003-07\end{array}$ & $\begin{array}{l}\mathrm{F}_{\mathrm{c}} \text {-value } \\
\text { (Reith, 2012) }\end{array}$ & $\begin{array}{c}\mathrm{F}_{\mathrm{c}} \text {-value based on } \\
\text { catalogue values }\end{array}$ \\
\hline Tilting ventilated slats & 0.25 & $\begin{array}{l}\mathrm{F}_{\mathrm{c}} \text {-value based on } \\
\text { measurements of } \\
\text { Baumann (FLL, 2014) }\end{array}$ \\
\hline $\begin{array}{l}\text { Venetian and fabric blinds with } \\
\text { high shading factor, ventilated }\end{array}$ & 0.25 & $0.05-0.2$ \\
\hline $\begin{array}{l}\text { Venetian blinds } \\
\text { Roller shutter }\end{array}$ & 0.40 & $0.11-0.13$ \\
\hline Canopy, loggia & 0.30 & \\
\hline $\begin{array}{l}\text { Fabric blinds } \\
\text { Shutters (operable panels) }\end{array}$ & $0.40-0.50$ & $0.07-0.19$ \\
\hline $\begin{array}{l}\text { Climbing plant on supporting } \\
\text { structure }\end{array}$ & $0.09-0.10$ & \\
\hline
\end{tabular}

every circumstance, are not yet available. Defining the direct solar transmission itself is considered as a preliminary result, which is, in the case of glass, $g_{\text {glass }} \approx 0.33$, and for a glass structure associated with common ivy shading, $\mathrm{g}_{\text {shaded }} \approx 0.04$. Based on the data above, $\mathrm{F}_{\mathrm{c}}$-value can be approximately calculated:

$\mathrm{F}_{\mathrm{c}} \approx 0.12$,

this can be compared to the values of venetian blinds in Table 1 - despite the fact that the measurement was conducted on technically better glass panes than the normal double-layer insulating glass with $\mathrm{g}=0.8$ value.

The data obtained from the computational process of the research values will be used for:

- comparison and providing data assisting the design of energy requirements and HVAC;

- the development of optical and thermal modelling of moveable glass structures associated with bio-shadings.

\section{Summary}

The analysis of the mechanism of action of bio-shadings and the data obtained during the research proved that the bio-shadings have an impact comparable to industrial shields:

- The plants expend at least $25 \%$ energy on photosynthesis and evaporation from the global solar radiation; thereby, plants act as if at least $25 \%$ less radiation energy is reaching the surface.

- The structure of the vegetation can significantly reduce the direct transmission, but on a cloudy day, it can also lead to a reduction in daylighting and reduce visual contact.

- On a summer's day, the temperature of plants remains below the air temperature; therefore, the heat load towards the environment will be reduced. Plants themselves provide ventilation by their physiological processes, thereby reducing the heat transfer towards the glazed structure.
- The evapotranspiration absorbs heat from its surroundings.

- Bio-shadings can function efficiently and safely on very windy, sunny days.

Data obtained by monitoring the effect of green shading systems can be compared to standard shading systems. According to our measurements, the bio-shader had $\mathrm{F}_{\mathrm{c}}$-value $\approx 0.12$, which can be commensurable to venetian blind $\mathrm{F}_{\mathrm{c}}$ values based on technical literature $\left(\mathrm{F}_{\mathrm{c}} \approx 0.05-0.12\right)$. Real comparison is only possible if the main constructions and the solar properties of the glazing structure are matching. This value also illustrates that the effect of a green shading system nearly approaches the effects of standard shading systems, even if we use glazing with better properties than the double clear glass $\left(\mathrm{U}=1.2 \mathrm{~W} / \mathrm{m}^{2} \mathrm{~K}\right)$ declared in the EN 13363 standard.

Consequently, bio-shadings may be considered not only as a new architectural element but can also play an important role in the energy balance of buildings in addition to numerous other environmental benefits.

Several factors hamper the research into bio-shadings, the definition of technical parameters, and the development of models for dynamic building simulations:

- due to the growth rate of plants, the establishment of the structure to be measured takes time;

- the growth of plants is affected by aspect, the local micro-climate and maintenance carried out;

- the properties of bio-shadings assembled with different types of plants vary significantly due to different growth characteristics including leaf size and density;

- the development and vitality of the plants may differ when the shading type is the same but established with a different type of plant. This can also have a significant impact on the shading simulation model; 
- it is not sufficient to carry out measurements on the same type of glass panes, since various versions of glass have different characteristics, and the effects of the same types of plant need to be tested on the various panes.

Despite the difficulties, the continuation of this research is extremely important, and hopefully, we will be able to continue walking on the path we have started.

\section{Acknowledgement}

The publication is linked to the research "Effects of plants as shading systems based on on-site measurements" within the framework of the project "Further analysis of the effective utilization of BME Odoo project Solar Decathlon" funded by the "New Széchenyi Plan ED_13-1-2013-0005 program".

I would like to thank the following people for their help and support during the research and writing of this paper:

Dániel Bakonyi (BME Department of Building Constructions) performed the bio-shading research with me as a joint project. Among numerous other aspects, I could count on his extensive knowledge of building physics and computer simulation knowledge.

Tamás Orbán (BME Thermal Physics Laboratory) developed a monitoring system, prepared the necessary data capture software, and helped to continuously monitor the measurements.

Orsolya Birtalan (MsC Architect) offered professional help.

Csaba Császár, my husband, who prepared the scaffolding necessary for the indoor devices and provided invaluable support throughout the project.

Katalin Csibi of MOBILANE East Europe Ltd provisioned the plants, the auxiliary equipment necessary and enthusiastically supported the project.

Zsófia Parti (MsC Architect) helped with the bibliography.

\section{References}

Anon. (2002) Democratic strategy. Project for District Centre, Zurich-Aussersihl. Techniques et architecture. 457 12/2001-01/2002, pp. 34-37

Anon. (2010a) Anthrazitfarbener Putz sorgt für wirkungsvollen Kontrast. $D B Z$ Deutsche BauZeitschrift. 2010(3), pp. 84-85. (in German)

Anon. (2010b) Ausgezeichnet - Fassadenpaneele aus Aluminium J73A. DBZ Deutsche BauZeitschrift. 2010(4), p. 79. (in German)

Anon. (2013a) Bibliothek in Liyuan. Detail. 53(5), pp. 488-491. (in German)

Anon. (2013b) Genialer Lokus - Toilettenbox, Lauterhofen. DBZ Deutsche BauZeitschrift. 2013(2), p. 116. (in German)

Anon. (2013c) Kindergarten und Grundschule in Saint-Denis. Detail. 2013(3), pp. $216-218$

Becker, G. (2014). Vékony üvegek és... Glasstec 2014. (Thin glasses and... Glasstec 2014). Metszet. 6(6), pp. 52-55. (in Hungarian)

Becker, G. (2015) Épületszerkezettan 3. Árnyékoló szerkezetek segédlet. (Building Construction 3. Shading Stuctures - technical manual). (in Hungarian) [Online]. Available from: http://epszerk.bme.hu/index. php?id=C0104 [Accessed: 15th December 2015]
Bojár, I. A. (2010) Terroir építészet - Bazaltbor-Laposa Pincészet, feldolgozó épület és Borhotel Badacsony - Kis Péter Építészműterme Kft. (Terroir architecture. Bazaltbor-Laposa Winery, processing workshop and Borhotel Badacsony). Octogon. 2010(7), pp. 111-117. (in Hungarian)

Csoknyai, T., Szalay, Zs. (2012) Az üvegezés és az energia. (Glazing and energy). In: Üveg az épitészetben. (Glass in architecture). Reith, A. (ed.), pp. 74-101. Terc Kiadó, Budapest. (in Hungarian)

Daniels, K. (1995) Technologie des ökologischen Bauens. Grundlagen und Maßnahmen, Beispiele und Ideen. Birkhauser Verlag, Berlin. 1995. (in German)

Enkerli, W. (2009) Der Ulm- und neue Anbau der Mensa Kantonschule Wettingen. Gesatnäzte Fassadenornamente. Façade. 2009(1), p. 53. (in German)

Enkerli, W. (2010) Neubau des City Garden Hotels in Zug. Kaleidoskopische Chromstahlhülle. Façade. 2010(3), pp. 55-59. (in German)

FLL (2014) Gebäude Begrünung Energie: Potenziale und Wechselwirkungen. FLL Forschungsgesellschaft Landschaftentwicklung Landschaftsbau e. V., Bonn. (in German)

Gábor, L. (1979) Épületszerkezettan IV. kötet. (Building Construction Vol IV.) Tankönyvkiadó, Budapest. (In Hungarian)

Gábor, L., Zöld, A. (1981) Energiagazdálkodás az épitészetben. (Energy management in architecture). Akadémiai Kiadó, Budapest. (in Hungarian)

Gutai, M. (2010) Jobb város, jobb élet - Világkiállítás Shanghaiban. (Better City, Better Life. World Expo in Shanghai). Octogon. 2010 (7), pp. 3541. (in Hungarian)

Hoyano, A. (1988) Climatological Uses of Plants for Solar Control and the Effects on the Thermal Environment of a Building. Energy and Buildings. 11(1-3), pp. 181-199. DOI: 10.1016/0378-7788(88)90035-7

Hrabovszky-Horváth, S. (2015) Az épülethatároló-szerkezetek és az éghajlatváltozás (The building enclosure structures and climate change). In: VI. Épületszerkezeti Konferencia - Homlokzatok, forma és szerkezet, Budapest, Nov. 24, 2015, Pataky, R,. Horváth, S. (eds), BME Épületszerkezettani Tanszék, Budapest. pp. 34-44. (in Hungarian)

Ip, K., Lam, M., Miller, A. (2010). Shading performance of a vertical deciduous climbing plant canopy. Building and Environment. 45(1), pp. 81-88. DOI: 10.1016/j.buildenv.2009.05.003

ITRS (2012) Richtlinie zur Beurteilung der Produkteingenschaften von Raffstoren/Aussenjalusien. (in German)

Jaafar, B., Said, I., Md Reba, M. N., Rasidi, M. H. (2013) Impact of Vertical Greenery System on Internal Building Corridors in the Tropic. Procedia - Social and Behavioral Sciences. 105, pp. 558-568. DOI: 10.1016/j.sbspro.2013.11.059

Käpplinger, C. (2013) Viel Lärm um einen gelungenen Stadtbaustein. Marthashof Berlin. DBZ Deutsche BauZeitschrift. 2013(9), pp. 46-51. (in German)

Keegan, E. (2012) The Centre for Interactive Research on Sustainability. Architect. 2012, pp. 101-104.

Kolleeny, J. (2010) Living on a Canal. Architectural Record. 198(4), pp. 66-71.

Köhler, M. (Ed.) (2012. Handbuch Bauwerksbegrünung. Planung - Konstrukion - Ausführung. Rudolf Müller Verlag, Köln. (in German)

Kreykenbohn, S. (2009) Oase mit Grün - Haus Polygreen in Northcota/Australien. DBZ Deutsche BauZeitschrift. 2009(11), pp. 46-49. (in German)

Krusche, P., Althaus, D., Gabriel, I., Weig-Krusche, M. (1982) Ökologisches Bauen. Umweltbundesamt. Bauverlag GmBH, Wiesbaden und Berlin, 1982. pp. 91-97. (in German)

Lee, G. S. (2006) Singapore Management University, City Campus. [Online]. Available from: http://archinect.com/gslee/project/singapore-management-university-city-campus [Accessed: 15th December 2015]

Ludescher, E. (2004) Schule Lauterach/A. In: Fassaden Atlas. Herzog, T., Krippner, R., Lang, W. (eds.), pp. 120-121. Walter de Gruyter, 2004. (in German) 
Manso, M., Castro-Gomes, J. (2015) Green wall systems: A review of their characteristics. Renewable and Sustainable Energy Reviews. 41, pp. 863-871. DOI: 10.1016/j.rser.2014.07.203

Mehl, R. (2015) Kristallin und Klimafreundlich. NEW Blauhaus, Mönchengladbach-Rheydt. DBZ Deutsche BauZeitschrift. 2015(9), pp. 26-33. (n German)

MSZ EN (2004) MSZ EN 13659:2004+A1:2009 Redőnyök. Teljesítőképességi követelmények a biztonság figyelembevételével. (Shutters. Performance requirements including safety). (in Hungarian)

MSZ EN (2005) MSZ EN 13363-2:2005 - Üvegezéssel társított napvédő eszközök. A napsugárzás- és fényátbocsátás kiszámítása. 2. rész: Részletes számítási módszer. (Solar protection devices combined with galzing. Calculation of solar and light transmittance. Part 2: Detailed calculation method). (in Hungarian)

MSZ EN (2011) MSZ EN 410:2011 - Építési üveg. Az üvegezés fénytechnikai és napsugárzási jellemzőinek meghatározása. (Glass in building. Determination of luminous and solar characteristics of glazing). (in Hungarian)

MSZ EN (2012) MSZ EN 12464-1:2012 - Fény és világítás. 1. rész: Belső téri munkahelyek. (Light and lighting. Lighting of work places. Part 1: Indoor work places). (in Hungarian)

Ormos, I. (1967) A kerttervezés története és gyakorlata. (The history and practice of garden design). Mezőgazdasági Kiadó, Budapest. (in Hungarian)

Ottelé, M., Perini, K., Fraaij, A.L.A., Haas, E.M., Raiteri, R. (2011) Comparative life cycle analysis for green façades and living wall systems. Energy and Buildings. 43(12), pp. 3419-3429. DOI: 10.1016/j.enbuild.2011.09.010

Papadakis, G., Tsamis, P., Kyritsis, S. (2001) An experimental investigation on the effect of shading with plants for solar control of buldings. Energy and Buildings. 33(8), pp. 831-836. DOI: 10.1016/S0378-7788(01)00066-4

Pataky, R. (2010) Zöldhomlokzatok és szabályozás. (Green façades and regulations.) Magyar Épitéstechnika. 48 (11), pp. 18-19. (in Hungarian)

Pataky, R. (2011) Zöldhomlokzatok szerkezeti megoldásai. (Structural solutions of green façades). MSc Thesis, BME Épületszigetelő Szakmérnöki Szak. (in Hungarian)

Pataky, R. (2012) Irányzatok különbözösége és azonossága. (Diversity and similarity of trends). In: III. Épületszerkezeti Konferencia - A környezettudatos építés szerkezetei, Nov 20, 2012. Pataky, R., Horváth, S. (eds.), BME Épületszerkezettani Tanszék, Budapest. pp. 16-18. (in Hungarian)

Pataky, R. (2013) Function, effect and examining possibilities of green shading. In: Architectural, Engineering and Information Sciences - 9th International PhD \& DLA Symposium: Abstracts Book. Ivanyi, P. (ed), Pécs, Magyarország, Oct. 21-22, 2013. University of Pécs Pollack Mihály Faculty of Engineering, Pécs.

Pataky, R. (2015a) Növényárnyékolók szerepe, összehasonlításuk gyári árnyékolókkal. (The role of bio-shading. A comparison with commercially available shading systems). In: VI. Épületszerkezeti Konferencia - Homlokzatok, forma és szerkezet, Budapest, Nov 24, 2015, Pataky, R., Horváth, S. (eds.), BME Épületszerkezettani Tanszék, Budapest. pp. 84-101. (in Hungarian)

Pataky, R. (2015b) Zöldhomlokzatok történeti áttekintése az ókortól a II. világháborúig, különös tekintettel a magyar vonatkozásokra. (Historical background of green façades from the Antiquity to World War II with a focus on Hungarian aspects). (manuscript) (in Hungarian)
Pataky, R., Áts, Á., Áts-Leskó, Zs., Birtalan, O. (2014) Constructional considerations for the mobile Plus-Energy House. Energy and Buildings. 83, pp. 195-208. DOI: 10.1016/j.enbuild.2014.07.015

Pawlitschko, R. (2013) Wellenmeer aus Alimuniumstreifen Messe Basel/Ch. DBZ Deutsche BauZeitschrift. 2013(9), pp. 28-37. (in German)

Pérez, G., Rincón, L., Vila, A., González, J. M., Cabeza, L. F. (2011) Behaviour of green façades in Mediterranean Continental climate. Energy Conversion and Management. 52(4), pp. 1861-1867.

DOI: 10.1016/j.enconman.2010.11.008

Pérez, G., Rincón, L., Vila, A., González, J. M., Cabeza, L. F. (2011) Green vertical systems for buildings as passive systems for energy savings. Applied Energy. 88(12), pp. 4854-4859. DOI: 10.1016/j.apenergy.2011.06.032

Schaefer, I. (2011) Soziales Wohnen im Passivhausstandard. Wohnanlage Lodenareal, Innsbruck/A. DBZ Deutsche BauZeitschrift. 2011(9), pp. 82-85. (in German)

Sheweka, S., Magdy, N. (2011) The Living walls as an Approach for a Healthy Urban Environment. Energy Procedia. 6, pp. 592-599.

DOI: 10.1016/j.egypro.2011.05.068

Sheweka, S. M., Magdy, N. M. (2012) Green Façades as a New Sustainable Approach. Towards Climate Change. Energy Procedia. 18, pp. 507-520. DOI: 10.1016/j.egypro.2012.05.062

Susorova, I., Angulo, M., Bahrami, P., Stephens, B. (2013) A model of vegetated exterior façades for evaluation of wall thermal performance. Building and Environment. 67, pp. 1-13. DOI: 10.1016/j.buildenv.2013.04.027

Széll, M. (2001). Transzparens épületszerkezetek. (Transparent building structures). Szerényi és Gazsó Bt., Pécs. (in Hungarian)

van Uffelen, C. (2011). Façade Greenery - Contemporary landscaping. Braun. Varga, M. (2009) Nagyságosságos - nézni is tereh. (Your Blessed Most Highness - that lures the sight). [Online]. Available from: http://epiteszforum. hu/nagysagossagos-nezni-is-tereh [Accessed: 15th December 2015] (in Hungarian)

Verein Deutscher Ingenieure, (VDI) (2015). VDI 2078:2015-05 - Berechnung der thermischen Lasten und Raumtemperaturen (Auslegung Kühllast und Jahressimulation). Richtlinie der Verein Deutsche Ingenieure (VDI) (in German)

Weinstein, N. (2010) Portland plans to save energy with a 200-ft high green wall. [Online]. Available from: http://www.greendiary.com/portlandplans-to-save-energy-with-a-200-ft-high-green-wall.html [Accessed: 15th December 2015]

Wong, N. H., Kwang Tan, A. Y., Tan, P. Y., Wong, N. C. (2009) Energy simulation of vertical greenery systems. Energy and Buildings. 41(12), pp. 1401-1408. DOI: 10.1016/j.enbuild.2009.08.010

Wong, N. H., Kwang Tan, A. Y., Chen, Y., Sekar, K., Tan, P. Y., Chan, D., Chiang, K., Wong, N. C. (2010). Thermal evaluation of vertical greenery systems for building walls. Building and Environment. 45(3), pp. 663672. DOI: 10.1016/j.buildenv.2009.08.005

Zuber, K. (2013). Ranken fürs Klima. [Online]. Available from: http://www adlershof.de/news/ranken-fuers-klima/ [Accessed: 15th December 2015] (in German) 